研究論文

木材を用いたものづくり学習における

中学生の環境意識尺度に関する研究

\author{
服部 浩司*・岳野 公人** \\ 金沢大学人間社会学域学校教育学類附属中学校*・滋賀大学 **
}

\title{
A Study on the Environmental Consciousness Scale of Junior High School Students Utilizing Wood to Learn about Production
}

\author{
Koji HATTORI* , Kimihito TAKENO** \\ Affiliated Junior High School, the School of Teacher Education, \\ College of Human and Social Science, Kanazawa University* \\ Shiga University** \\ （受理日 2015 年 8 月 26 日）
}

The purpose of this study was to identify the environmental consciousness of junior high school students who learned about production while working with wood in a technology education course. We prepared a consciousness questionnaire to clarify the level of environmental consciousness of the junior high school students. The questions asked were made using the answers to a precedent study and free description investigation related to woodworking production processes. We examined The validity and reliability of the questions and carried out the investigation with the cooperation of 500 junior high school students who studied the contents of "Techniques about Materials and Processing" in Aichi, Ishikawa and Nagasaki prefectures. Furthermore, we considered whether or not it is possible to suggest a curriculum that promotes environment-conscious behavior. As a result, the following issues were clarified.

1) We were able to make a consciousness scale to understand the level of environmental consciousness of the junior high school students learning about production while working with wood.

2) As a result of having examined the environmental consciousness structure of the junior high school students learning about production while working with wood, we were able to extract five factors by factor analysis.

3) From the results of relevance regarding the average of factor scores and grades, we proposed a curriculum about the need for thinning and various functions of wood placing an emphasis on environment-conscious behavior.

4) From the results of relevance regarding the average of factor scores and gender, we could show that it is necessary to put emphasis on design when boys are learning about production.

Key words: Environmental consciousness scale, factor analysis, junior high school students, production learning, school education

問い合わせ先 $\quad$ T 921-8105 石川県金沢市平和町 1-1-15 金沢大学人間社会学域学校教育学類附属中学校 


\section{I はじめに}

現在、自然環境の破壊が問題となっており、そ の解決策の一つとして環境教育の実践が求められ ている。環境省は、環境教育の推進に関する基本 的な方針を示し、環境教育の重要な目的を、環境 保全行動の促進や自発的に取り組む態度の育成と 位置づけている（環境省 2004）。

また、学校教育の中学校段階では社会科（中村 2009）や理科（下山田 2008）など様々な教科で 環境教育に関する研究が実施され、技術・家庭科 技術分野（以下技術科）もその役割の一端を担っ ている。技術科における環境教育に関しては、中 学校学習指導要領解説技術 - 家庭科編「A 材料と 加工に関する技術」の内容に、材料の再資源化や 廃棄物の発生抑制など、材料と加工に関する技術 が自然環境の保全に大きく貢献していることにつ いて理解させることや、技術が自然環境の保全に も貢献していることを踏まえ、よりよい社会を築 くために、材料と加工に関する技術を適切に評価 し、活用する能力と態度を育成するとあり、もの づくり学習を通して環境配慮行動を実践する態度 を育成することが求められている（文部科学省 2008 (a))。

環境配慮行動に関する先行研究では、諏訪ら （2006）により関心 ・動機・行動基本モデルが構 築され、環境配慮行動は、関心と動機によって規 定され、動機は関心によって規定されると示して いる。そのため、環境配慮行動を実践しようとす る態度を育成するには、環境問題を認識し、環境 問題に関心を持つことが重要である。

一方、技術科の「A材料と加工に関する技術」 の内容では、木材を用いた教材の授業実践を多数 確認することができる。橘田（1990）は技術科の ものづくり教育を手工的労作教育と捉え、教育用 材料としての木材の有効性を示している。田口 （2010）は国産材を利用することは、ウッドマイ レージの点で環境に与える負荷を軽減するととも に、林業の活性化につながり、ひいては健全な森 を育て森林のもつ多面的機能が発揮されると述 べ、木材を取り上げた授業に関して、環境教育の
有効性を示唆している。このように木材は教育用 材料として有効なものであり、環境教育が求めら れている今日、さらに注目される材料である。そ こで本研究では木材を用いたものづくり学習に着 目した。

ものづくり学習と環境教育に関する先行研究に は、以下のようなものがある。岳野ら（2007）は、 里山より採取した自然木を用いたものづくり教材 の開発を行い、ものづくり学習を通した環境教育 を実践し、質問紙による意識調査からものづくり 学習における環境教育の有効性を示唆している。 また、木村ら（2009）は技術科の「材料取り」の 授業に関して、取り出す部材の配置を工夫し、再 利用できる材料の大きさを増やすことにより、廃 棄物そのものを減少させることを目的とした授業 実践を行い、アンケート調查より身近なゴミ問題 を含めた環境問題への意欲・態度を育成できる授 業実践の有効性を示唆している。杉村ら（1999） も廃裹物、資源の有効利用に着目し、木くずから 作ったパーティクルボードを用いてLife Cycle Assessment（LCA）の理解・活用を目的とした 授業実践を行っている。実践に対する生徒の感想 を分析した結果、LCAの概念を取り入れた製品 を製造することにより、生産－流通－消費－廃棄 一再生という一連の循環過程についての環境負荷 を考えて、製品を選択する際に考慮することがで きるように生徒の視点が広げられたと述べてい る。

しかし、以上のものづくり学習と環境教育に関 する先行研究に見られる質問紙のアンケート項目 は研究者が準備した項目に対して被験者が回答 し、ものづくりを経験した被験者の環境意識を分 析することに一部課題を残していることを指摘で きる。研究者のみが質問項目を作成した場合、本 質的な内容や定義から離れた項目を作成し、測定 内容があいまいな項目が混入する恐れがある。鎌 原ら（1998）は質問項目の作成に関して、測定内 容や概念の定義を明示し、作成した項目がその定 義に合致しているか否か専門家の判定を依頼し、 内容的妥当性を検討する必要性を述べている。

環境教育を実践するために有効な材料である木 
材を用いたものづくり学習における中学生の環境 意識尺度を作成することができれば、技術科の授 業実践を環境的視点より評価することができる。 またその評価結果を受けて授業改善、教材選択な どに活用することにより、教員の授業力向上につ ながることも期待できる。

そこで本研究では、技術科の木材を用いたもの づくり学習における中学生の環境意識を明らかに するための環境意識尺度を作成することを目的と した。さらに、作成した尺度を用いて得られた知 見から、環境配慮行動を導く学習指導法の提案を 行う。

\section{II 研究方法}

環境意識に関する先行研究には以下のようなも のがある。中野ら（2007）は、環境配慮行動を促 す環境学習を開発・推進するためには、子どもの 環境保全に対する実行力が、どのような認知や自 己評価に基づいているのかを探る必要があると指 摘し、児童生徒の環境配慮行動に関する研究を行 い、広瀬（1994）の「環境配慮行動の要因連関モ デル」を基に、「環境認知」「行動評価」、環境 保全態度」、環境配慮行動」「環境保全認識」の 5 因子の妥当性と信頼性を確認している。また、 黒沢ら（2012）は大学の環境教育に寄与する目的 で、教員を目指す大学生の環境および環境教育に 関する意識を把握する意識尺度の研究を行い、 「環境問題の重要性」「環境問題への興味・関 心」、環境配慮行動」の 3 因子 26 項目からなる環 境に対する意識尺度、「環境教育の必要性」「環 境教育への興味・関心」、「環境教育に対する意 欲」「環境教育への自信」の 4 因子 33 項目からな る環境教育に対する意識尺度を構成している。先 行研究では、技術科教育の観点から中学生のもの づくり学習における環境意識を明らかにした研究 は認められなかった。

そこで本研究では、木材を用いたものづくり学 習に対する中学生の環境意識を明らかにするため に、意識調査票を作成した。質問項目は、先行研 究やものづくり教室における自由記述調査の回答 を利用して作成した。また、質問項目の妥当性や
信頼性を検討し、技術科を学習した中学生を対象 とした本調査を実施した。

\section{1 質問項目の作成}

調査票の作成においては、ものづくり学習の意 義に含まれる環境意識（岳野・鬼藤 2008）や大 学などで開催されたものづくり教室（岳野・笠木 2007）（岳野 2013）の自由記述形式の調査の回答 から、環境意識を調査する46項目を作成した。 ここでのものづくりの主な題材は、自然木を利用 したバターナイフやスプーンの製作であった。ま た、鎌原らの質問紙作成手順に基づき、内容的妥 当性を検討するため、教職経験 10 年以上の現職 の技術科教員 2 名に、作成した質問項目の妥当性 の検討について依頼を行った。その結果、内容の 削除と追加を行い、質問項目を52項目とした。

\section{2 本調查}

生徒には、調査結果は成績には関係ないことを 伝え、20分程度で回答を求めた。調査時期は 2013年の 9 月であった。

対象者は、愛知県、石川県、長崎県の技術科教 員 3 名の協力のもと、各学校で「A材料と加工に 関する技術」の内容を学習した中学生 500 名とし た。有効回答数は 375 名、無効回答数は 125 名、 有効回答率は $75 \%$ であった。

調査は 5 件法の回答で求め、集計では肯定的な 回答から 5 点、 4 点、 3 点、 2 点、 1 点と得点化した。

\section{III 調査結果および考察}

調査に用いる質問項目の信頼性を検討するとと もに、調査より得られた結果が学習効果のみであ ることを確認するため、調査地域による潜在的な 環境意識の差の有無を検討した。さらに、作成し た尺度を用いて得られた知見から、環境配慮型行 動を導く学習指導法について検討および提案を 行った。

\section{1 本調査の信頼性の検討}

本調査の項目に関して信頼性を検討した結果、 Cronbachの $\alpha$ 係数は 0.96 となり、調査票の信頼 
性を確認した。調査票の信頼性については、この 後検討する因子分析においても、項目の精選が行 われ、その都度算出することとした。

諸手続きを経て作成された、木材を用いたもの づくり学習における中学生の環境意識に関する調 査は、先行研究を見る限り認められなかった。し たがって、本研究で作成した調査票は、木材を用 いたものづくり学習における中学生の環境意識に ついて把握する有効な尺度になると考えられる。

\section{2 調査地域による環境意識差の検討}

分析を行う前に調査地域による環境意識の差を 検討した。有効回答者 (石川県 176 名、愛知県 105名、長崎県 94 名）である合計 375 名を対象に 1要因の分散分析を実施した。表1は、各条件の 平均值と標準偏差を示したものである。分散分析 の結果、表 2 に示したように条件の効果は見られ なかった。これにより、地域による環境意識の差 は有意でないことが明らかになったため、3県の 調查票より得られた結果をまとめて分析すること にした。

表 1 調査地域による環境意識の平均値及び標準偏差

\begin{tabular}{cccc}
\hline & & 環境意識 \\
& 石川県 & 愛知県 & 長崎県 \\
\hline \hline $\mathrm{N}$ & 176 & 105 & 94 \\
$\overline{\mathrm{X}}$ & 0.08 & 0.04 & -0.11 \\
$\mathrm{SD}$ & 0.89 & 1.12 & 1.02 \\
\hline
\end{tabular}

表2 地域差における分散分析表

\begin{tabular}{ccccc}
\hline SV & SS & df & MS & F \\
\hline \hline 条件 & 2.133 & 2 & 1.07 & 1.07 \\
偶然誤差 & 369.787 & 372 & 0.99 & \\
\hline 全体 & 371.919 & 374 & ${ }^{*} \mathrm{p}<.01{ }^{*} \mathrm{p}<.05 \dagger$ : 有意傾向
\end{tabular}

\section{3 木材を用いたものづくり学習を受けた中学生 の環境意識構造}

技術科で木材を用いたものづくり学習を受けた 中学生の環境意識を明らかにするために、妥当性 の認められた 52 項目について主因子法、Promax 回転による因子分析を行った。今回の因子分析 は、探索的に実施し、木材を用いたものづくり学
習を受けた中学生の意識構造の把握を目的とし た。計算には、エクセル統計 2012 用いた。また、 因子分析の方法は、50\%前後の因子寄与率を基準 とし、固有值が 0.4 以上、因子間の固有值が 0.1 以 上となるように計算を繰り返した。この方針に基 づき必要に応じて質問項目を削除した。最終的 に、32 項目の因子分析を実施し、5因子のまとま りが妥当であると判断した（表3）。32項目の場 合の $a$ 係数は 0.95 となり、 52 項目の場合よりも 若干下がったが、信頼性係数の判定基準は 0.7 以 上であるため、十分に信頼性が認められる。

因子分析の結果をみると、第 1 因子は「ものづ くりを通して、環境問題について考えることがで きた」、「この経験をいかして環境問題を改善する ための方法を考えることができる」、「ものづくり の経験を生かして、自分の行動を環境問題と結び 付けたい」などの項目の固有值が高かった。これ らは、環境問題への関わりについて、解決行動、 行動への変換を示す積極的な意識と捉えることが できる。このことから、第1因子を「ものづくり を動因とした環境問題への興味・関心」と解釈し た。

第2因子は「実際に森の中に入ってみたい」「自 分で森から材料を調達してみたい」、「動植物の生 態など新たな発見や刺激を感じてみたい」などの 項目の固有值が高かった。これらは、自然体験へ の積極的な関わりと捉えることができる。このこ とから、第 2 因子を「自然体験活動への意欲」と 解釈した。

第3因子は「なるべくごみを増やさないように したい」、「ポイ捨てなどの環境破壊行為はしない ようにしようと考えた」、無駄なものは買わない ようにしようと考えた」などの項目の固有值が高 かった。これらは、日常生活における環境保全行 動を示す積極的な意識であると捉えることができ る。このことから、第3因子を「日常生活におけ る環境保全意識」と解釈した。

第 4 因子は「木工について新たに興味をもっ た」、「も立木工作業をしてみたい」、「ものづ くり活動の経験から木工への興味関心が増した」 などの項目の固有值が高かった。これらは、木材 
表3 因子分析の結果

\begin{tabular}{|c|c|c|c|c|c|c|c|}
\hline 変数 & & 因子1 & 因子2 & 因子3 & 因子 4 & 因子5 & 共通性 \\
\hline 47 & ものづくりを通して、環境問題について考えることができた & 0.792 & 0.002 & -0.068 & 0.015 & 0.025 & 0.632 \\
\hline 52 & この経験をいかして環境問題を改善するための方法を考えることができる & 0.710 & -0.052 & 0.116 & 0.010 & -0.003 & 0.520 \\
\hline 50 & ものぶくりの経験を生かして、自分の行動を環境問題と結び付けたい & 0.696 & 0.054 & 0.060 & 0.035 & -0.056 & 0.495 \\
\hline 48 & ものづくりをしながら、木が生い茂っている森について考えた & 0.686 & 0.218 & -0.156 & -0.098 & 0.104 & 0.563 \\
\hline 49 & 作業を通して、森や木を見る目が変ると思う & 0.672 & 0.128 & -0.166 & 0.068 & -0.017 & 0.500 \\
\hline 45 & 自分が環境に対して何ができるかを考えた & 0.613 & -0.108 & 0.148 & 0.040 & 0.045 & 0.412 \\
\hline 42 & ごみの分別行為について今まで以上に努力しようと考えた & 0.489 & 0.017 & 0.317 & -0.024 & -0.116 & 0.354 \\
\hline 33 & 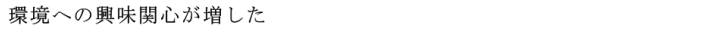 & 0.484 & -0.030 & 0.116 & 0.170 & 0.100 & 0.287 \\
\hline 40 & 自分の行動を環境問題と結びつけて考えられるようになった & 0.471 & -0.026 & 0.115 & 0.121 & 0.105 & 0.262 \\
\hline 46 & ものづくり活動は環境保全に対して何らかの意味がある & 0.438 & 0.009 & 0.183 & -0.089 & 0.122 & 0.248 \\
\hline 29 & 体験することで自然環境について自分の言葉で伝えられると考えた & 0.404 & 0.055 & -0.065 & 0.144 & 0.242 & 0.250 \\
\hline 18 & 実際に森の中に入ってみたい & -0.042 & 0.862 & 0.002 & 0.002 & -0.119 & 0.759 \\
\hline 17 & 自分で森から材料を調達してみたい & -0.097 & 0.720 & 0.022 & 0.092 & 0.093 & 0.545 \\
\hline 19 & 動植物の生態など新たな発見や刺激を感じてみたい & 0.006 & 0.714 & 0.013 & -0.010 & 0.018 & 0.510 \\
\hline 21 & 木に触れ森の中を歩くことで感受性を高めようと考えた & 0.107 & 0.640 & -0.191 & 0.111 & 0.168 & 0.497 \\
\hline 37 & 緑化活動や木の実の育成をしたい & 0.225 & 0.592 & 0.112 & -0.029 & -0.046 & 0.417 \\
\hline 11 & 植林活動をしてみたい & -0.023 & 0.587 & 0.158 & -0.004 & 0.077 & 0.376 \\
\hline 43 & 自分で花や野菜などを育ててみたい & 0.185 & 0.460 & 0.174 & -0.017 & -0.118 & 0.290 \\
\hline 1 & なるバくごみを増やさないようにしたい & -0.045 & 0.097 & 0.641 & -0.121 & 0.097 & 0.447 \\
\hline 34 & ポイ捨てなどの環境破壞行為はしないようにしようと考えた & -0.035 & 0.013 & 0.623 & 0.204 & -0.116 & 0.445 \\
\hline 4 & 無䭾なものは買わないようにしようと考えた & 0.029 & 0.009 & 0.520 & 0.054 & 0.023 & 0.275 \\
\hline 5 & 物を大切に扱おうと考えた & -0.055 & -0.051 & 0.505 & -0.006 & 0.211 & 0.306 \\
\hline 2 & 割りばし、レジ袋などについて自分のものを使おうと苊えた & 0.032 & 0.222 & 0.482 & -0.033 & 0.107 & 0.295 \\
\hline 51 & 資源を有効に利用しようと思う & 0.346 & -0.002 & 0.448 & -0.051 & 0.023 & 0.323 \\
\hline 35 & 環境破壊行為をしている人がいたら注意したい & 0.130 & -0.036 & 0.436 & 0.180 & 0.054 & 0.243 \\
\hline 22 & 木工について新たに興味をもった & -0.019 & 0.019 & -0.014 & 0.788 & 0.131 & 0.639 \\
\hline 24 & もう一度木工作業 & 0.092 & 0.041 & 0.025 & 0.660 & -0.136 & 0.465 \\
\hline 20 & ものづくり活動の経験から木工への興味関心が増した & 0.003 & 0.290 & 0.115 & 0.504 & 0.023 & 0.352 \\
\hline 28 & 木の色、堅さ、大きさなどの知識について興味がわいた & 0.176 & 0.175 & 0.064 & 0.428 & -0.043 & 0.250 \\
\hline 8 & 資源の循環や環境について意識が高まった & 0.145 & -0.038 & 0.155 & -0.045 & 0.641 & 0.459 \\
\hline 6 & 資源の有効活用について考えた & 0.128 & 0.046 & 0.170 & -0.079 & 0.549 & 0.355 \\
\hline 9 & 材料の生育環境について学びたい & 0.070 & 0.072 & -0.037 & 0.295 & 0.437 & 0.290 \\
\hline & 因子寄与 (負荷量の二乗和) & 4.297 & 3.362 & 2.385 & 1.797 & 1.222 & 13.064 \\
\hline & 因子寄与率 & $35.79 \%$ & $5.52 \%$ & $3.89 \%$ & $2.51 \%$ & $2.07 \%$ & $49.78 \%$ \\
\hline
\end{tabular}

加工への興味・関心と捉えることができる。この ことから、第 4 因子を「木材加工への興味・関心」 と解釈した。

第5因子は「資源の循環や環境について意識が 高まった」、「資源の有効活用について考えた」、 「材料の生育環境について学びたい」の項目の固 有值が高かった。これらは、資源と環境保全との 関わりについての関心や意欲を示す意識であると 捉えることができる。このことから、第 5 因子を 「資源に関する環境保全意識」と解釈した。

先行研究における大学生の環境意識を把握する ための因子項目と本研究より得られた因子項目を 比較すると、環境や環境問題に対する興味・関心 を因子項目としているところに共通性を確認する ことができる。しかし、先行研究では教員を目指 している大学生を対象に調査しているのに対して 本研究は技術科という特定の教科に対する環境意
識を評価しているため、本研究の因子項目には 「木材加工への興味・関心」、「資源に関する環境 保全意識」など技術科特有の内容が含まれてい る。小学校や中学校による学校単位や、様々な教 科で環境教育が実践されている今日、その実践の 成果を検討するためには、実践に適した尺度を作 成する必要があると考えられる。

\section{4 木材を用いたものづくり学習における中学生 の環境意識の実態}

因子分析の結果、因子得点が得られる。この因 子得点を利用し、学年、性別、および因子要因に 対して、分散分析を実施した。学年別因子得点の 平均值及び標準偏差を示したものが表4である。 学年、因子における因子得点の平均值を図 1 に示 した。これらの得点を用いて、学年、因子におけ る 2 要因の分散分析を実施した (表5)。その結果、 
表4 学年別因子得点の平均值及び標準偏差
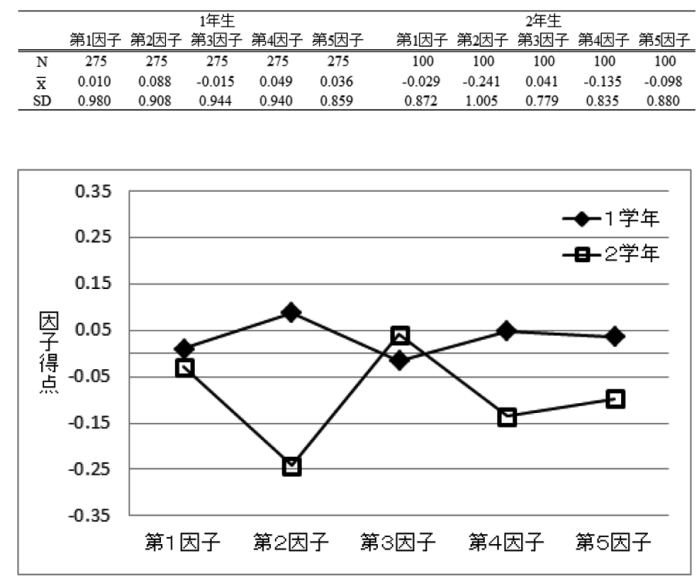

図 1 学年、因子における因子得点の平均値

表5 学年、因子における分散分析表

\begin{tabular}{|c|c|c|c|c|c|}
\hline SV & SS & df & MS & $\mathrm{F}$ & \\
\hline 学年要团 & 5.838 & 1 & 5.838 & 2.125 & \\
\hline 個人差 & 1024.542 & 373 & 2.747 & & \\
\hline 园子要固 & 1.359 & 4 & 0.340 & 0.935 & \\
\hline 交互作用 & 6.241 & 4 & 1.560 & 4.293 & ** \\
\hline 偶然䛱差 & 542.219 & 1492 & 0.363 & & \\
\hline 全体 & 1580.199 & 1873 & $* * p<.01$ & $05 \div: 7$ & 意傾向 \\
\hline
\end{tabular}

表 6 学年要因 $\times$ 因子の交互作用分析表

\begin{tabular}{|c|c|c|c|c|c|}
\hline SV & SS & df & MS & & $\mathrm{F}$ \\
\hline 学年要因 at 第1因子 & 0.112 & 1 & 0.112 & & 0.123 \\
\hline (個人差 at 第1团子 & 340.172 & 373 & 0.912 & ) & \\
\hline 学年要因 at 第2因子 & 7.941 & 1 & 7.941 & & $9.044 * *$ \\
\hline （個人差 at 第2因子 & 327.518 & 373 & 0.878 & ) & \\
\hline 学年要因 at 第3因子 & 0.224 & 1 & 0.224 & & 0.273 \\
\hline （個人差 at 第3因子 & 305.973 & 373 & 0.820 & ) & \\
\hline 学年要因 at 第4因子 & 2.496 & 1 & 2.496 & & $2.977 \dagger$ \\
\hline (個人差 at 第4因子 & 312.717 & 373 & 0.838 & ) & \\
\hline 学年要因 at 第5因子 & 1.305 & 1 & 1.305 & & 1.736 \\
\hline （個人差 at 第 5 因子 & 280.382 & 373 & 0.752 & ) & \\
\hline 因子要因 at 1 年生 & 0.888 & 4 & 0.222 & & 0.611 \\
\hline 因子要因 at 2 年生 & 6.712 & 4 & 1.678 & & $4.617 * *$ \\
\hline （個人差 $\times$ 因子要因 & 542.2194 & 1492 & 0.363418 & & \\
\hline
\end{tabular}

表7 2 年生の多重比較の結果

左項vs. 右項 第 2 因子 第 3 因子 第 4 因子 第 5 因子 第1因子 第2因子 第3因子 第4因子

$\begin{array}{lll}= & = & = \\ < & = & = \\ & < & = \\ & & =\end{array}$

不等号 $\mathrm{p}<0.5$, 等号n.s

交互作用は有意であった（F (4,1492）=4.293, $\mathrm{p}<0.1)$ 。

そこで、水準ごとに単純主効果を分析した結
表8 性別別因子得点の平均値及び標準偏差
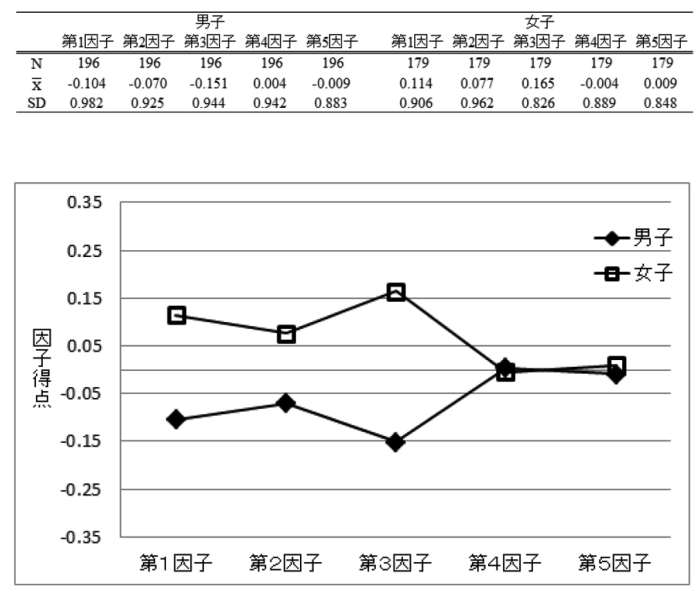

図2 性別、因子における因子得点の平均値

表9 性別、因子における分散分析表

\begin{tabular}{crcccl}
\hline SV & \multicolumn{1}{c}{ SS } & df & MS & F & \\
\hline 性別要团 & 8.924 & 1 & 8.924 & 3.264 & $\dagger$ \\
個人差 & 1019.849 & 373 & 2.734 & & \\
\hline 因子要团 & 0.014 & 4 & 0.004 & 0.010 & \\
交互作用 & 6.896 & 4 & 1.724 & 4.735 & $* *$ \\
偶然誤差 & 543.172 & 1492 & 0.364 & & \\
\hline 全体 & 1578.854 & 1873 & $* * \mathrm{p}<.01 * \mathrm{p}<.05 \dagger$ :有意傾向
\end{tabular}

表 10 性別要因 $\times$ 因子の交互作用分析表

\begin{tabular}{|c|c|c|c|c|}
\hline SV & SS & df & MS & F \\
\hline 性別要因 at 第1因子 & 4.445 & 1 & 4.445 & $4.937 *$ \\
\hline （個人差 at 第1团子 & 335.839 & 373 & 0.900 & ) \\
\hline 性別要因 at 第2因子 & 2.023 & 1 & 2.023 & 2.263 \\
\hline （個人差 at 第2团子 & 333.436 & 373 & 0.894 & ) \\
\hline 性別要因 at 第3团子 & 9.316 & 1 & 9.316 & $11.705 * *$ \\
\hline (個人差 at 第3因子 & 296.881 & 373 & 0.796 & ) \\
\hline 性別要因 at 第4因子 & 0.006 & 1 & 0.006 & 0.007 \\
\hline （個人差 at 第4团子 & 315.208 & 373 & 0.845 & ) \\
\hline 性別要因 at 第5因子 & 0.030 & 1 & 0.030 & 0.039 \\
\hline (個人差 at 第5团子 & 281.658 & 373 & 0.755 & ) \\
\hline 因子要团 at 男子 & 3.142 & 4 & 0.786 & $2.158 \dagger$ \\
\hline 因子要因 at 女子 & 3.767 & 4 & 0.942 & $2.587 *$ \\
\hline （個人差 $\times$ 因子要团 & 543.172 & 1492 & 0.364 & ) \\
\hline
\end{tabular}

果、表 6 のようになった。学年要因は第 2 因子に おいて $1 \%$ 水準で有意であり、第 4 因子において 有意傾向が見られた。第2因子は「自然体験活動 への意欲」、第4因子は「木材加工への興味・関心」 であり、 1 年生よりも 2 年生の方が有意に低く、 自然体験活動や木材加工に関する意識が低いこと が確認できた。第 2 因子、第 4 因子以外の因子に おいて有意差は認められなかった。因子要因は 2 年生において $1 \%$ 水準で有意であった。単純主効 果の認められた 2 年生における因子要因について、 
表 11 男子の多重比較の結果

$\begin{array}{ccccc}\text { 左項vs.右項 } & \text { 第2因子 } & \text { 第3因子 } & \text { 第4因子 } & \text { 第5因子 } \\ \text { 第1因子 } & = & = & = & = \\ \text { 第2因子 } & & < & = & = \\ \text { 第3因子 } & & & < & < \\ \text { 第4因子 } & & & & =\end{array}$

不等号 $\mathrm{p}<0.5$, 等号 $\mathrm{n.s}$

表12 女子の多重比較の結果

$\begin{array}{ccccc}\text { 左項vs.右項 } & \text { 第2因子 } & \text { 第3因子 } & \text { 第4因子 } & \text { 第5因子 } \\ \text { 第1因子 } & = & = & = & = \\ \text { 第2因子 } & & = & = & = \\ \text { 第3因子 } & & & < & < \\ \text { 第4因子 } & & & & = \\ & \text { 不等号 } \mathrm{p}<0.5 \text {, 等号 } \mathrm{n} . \mathrm{s}\end{array}$

多重比較を実施した結果、表7のようになった。 LSD 值は 0.167 であり、この值よりも大きい場合、 有意差があることになる。第 1 因子「ものづくり を動因とした環境問題への興味・関心」、第 3 因 子「日常生活における環境保全意識」よりも第 2 因子「自然体験活動への意欲」は意識が低く、第 3 因子「日常生活における環境保全意識」よりも 第 4 因子「木材加工への興味・関心」の方が意識 は低い結果となった。

性別別因子得点の平均值及び標準偏差を示した ものが表 8 である。性別、因子における因子得点 の平均值を図 2 に示した。これらの得点を用いて、 性別、因子における2 要因の分散分析を実施した (表9）。その結果、交互作用は有意であった（F $(4,1492)=4.735, \mathrm{p}<0.1)$ 。

そこで、水準ごとに単純主効果を分析した結 果、表10のようになった。性別要因は第 1 因子に おいて $5 \%$ 水準で有意であり、第 3 因子は $1 \%$ 水準 で有意であった。第1因子は「ものづくりを動因 とした環境問題への興味・関心」第3因子は「日 常生活における環境保全意識」であり、男女を比 較すると、いずれも女子の方が有意に高く、環境 問題への関心や日常生活における環境保全への意 識は高い結果となった。第 1 因子、第 3 因子以外 の因子において有意差は認められなかった。因子 要因は男子において有意傾向、女子において $5 \%$ 水準で有意差が認められた。単純主効果の認めら れた男子、女子における因子要因について、多重
比較を実施した結果、男子は表 11 、女子は表 12 のようになった。男子のLSD值は 0.119、女子の

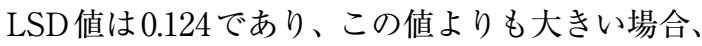
有意差があることになる。男子は第 2 因子「自然 体験活動への意欲」、第 4 因子「木材加工への興 味・関心」第5因子「資源に関する環境保全意識」 よりも第3因子「日常生活における環境保全意識」 の方が意識は低い結果となった。女子は、第 3 因 子「日常生活における環境保全意識」が第 4 因子 「木材加工への興味・関心」、第 5 因子「資源に関 する環境保全意識」よりも意識が高いことが分 かった。

\section{5 考察}

学年、因子における因子得点を用いた分散分析 の結果、交互作用において $1 \%$ 水準で有意であっ たため、単純主効果を分析した結果、学年要因の 第 2 因子「自然体験活動への意欲」、第 4 因子「木 材加工への興味・関心」において 2 年生は 1 年生 に比べ有意に低い結果となった。第 2 因子、第 4 因子は「A材料と加工に関する技術」の内容に関 連性が高い項目であり、技術科の教育課程では、 1 年時に「A 材料と加工に関する技術」を学習す る場合が多く、そこで取り扱う教材には木材を用 いたものが多く見られる。学習指導要領「A材料 と加工に関する技術」の内容には、材料の特徴と 利用方法を知ることとあるため、木材は苗を育 て、植樹することにより再生可能な資源であるこ とや、人工林では間伐などの管理作業が必要であ るなどの学習内容を扱うことが予想される（文部 科学省 $2008(\mathrm{~b}))$ 。そのため、1年生では植林活 動などの自然体験への意欲や木材加工への興味 · 関心は高いが、 2 年生では、はんだごて等を使用 した機械的な体験活動を行うため、自然体験や木 材加工への意欲が低下していると考えられる。こ れより、現状の学習指導では「A材料と加工に関 する技術」の学習内容に関連する環境意識は、新 たな学習内容に意識が移行しやすい傾向にあると 考えられる。さらに、因子要因は 2 年生において $1 \%$ 水準で有意であったため、LSD 法による多重 比較を実施した結果、第2因子「自然体験活動へ 
の意欲」は第 1 因子「ものづくりを動因とした環 境問題への興味・関心」、第 3 因子「日常生活に おける環境保全意識」に比べ有意に低く、第 4 因 子「木材加工への興味・関心」は第3因子「日常 生活における環境保全意識」に比べ有意に低い結 果となった。先述したように 2 年生では機械的な 体験活動を行うため、自然体験や木材加工への意 欲が低下していると考えられる。他の因子に関し ては学年が上がっても環境意識に関する意識の変 化は見られない。諏訪ら (2006)の提案する関心 ・ 動機・行動基本モデルを検討すると、環境配慮行 動を実践しようとする態度を育成するには環境問 題に関心を持つことが必要である。自然体験活動 への意欲や木材加工への興味・関心の意識低下を 防ぐ手立てとして、ものづくり学習の内容改善が 考えられる。学年を問わずものづくりに対する生 徒の製作意欲は高いと推測されるため、ものづく りと自然環境とのつながりを高めた学習に指導の 重点を置くことが必要であり、間伐の必要性や森 の多様な機能など、木や森の学習内容をカリキュ ラムに取り入れることが有効と考えられる。

性別、因子における因子得点を用いた分散分析 の結果、交互作用において $1 \%$ 水準で有意であっ たため、単純主効果を分析した結果、性別要因の 第1因子「ものづくりを動因とした環境問題への 興味・関心」、第3因子「日常生活における環境 保全意識」において男子は女子に比べ有意に低い 結果となった。ものづくりなどの体験活動に関し ては、男女による有意差は見られないため、男子 はものづくりなどの体験活動と環境保全意識を関 連づけにくい傾向であると考えられる。さらに、 因子要因は男子で有意傾向、女子で $5 \%$ 水準の有 意差を示したため、LSD法による多重比較を実 施した結果、男子は第3因子「日常生活における 環境保全意識」が第 2 因子「自然体験活動への意 欲」、第 4 因子「木材加工への興味 - 関心」、第 5 因子「資源に関する環境保全意識」と比較して有 意に低く、女子は第 3 因子「日常生活における環 境保全意識」が第 4 因子「木材加工への興味・関 心」、第 5 因子「資源に関する環境保全意識」と 比較して有意に高い結果となった。男子は先述し
たように、体験活動と環境保全意識を関連付けに くく、特に日常生活において意識の関連付けが薄 い。一方女子は日常生活と環境保全意識に関して 意識が高い。田口（2010）によると、6歳〜 15歳 の览童・生徒の生活体験に関する調査の結果、女 子の方が家庭に関する生活体験は男子に比べ有意 に高いことを示している。このことより、生活に 関心の高い女子の方が日常生活に関する環境意識 も高まったのではないかと考えられる。男子の日 常生活における環境保全意識を向上させる手立て として、のこぎり引きや鉋がけなどの製作作業で はなく、製作品の設計に学習指導の重点を置くこ とが重要であると考えられる。現在身の回りには 環境保全を考慮した製品が多数存在し、生徒は消 費者としてそれらの製品と関わることになる。設 計の学習では、3RやLCAなどの観点から、環境 を配慮した製品とはどのようなものなのかを思考 する場面が多く存在する。環境保全を考慮した製 品の必要性を学習し、その知識を基に設計を行う ことで、資源の有効利用や物を大切に扱うなどの 意識が向上していくと考えられる。

\section{N まとめ}

本研究では、技術科の木材を用いたものづくり 学習における中学生の環境意識を明らかにするた めの環境意識尺度を作成することを目的とした。 質問項目は、先行研究やものづくり教室における 自由記述調查の回答を利用して作成した。質問項 目の妥当性や信頼性を検討し、技術科を学ぶ 500 名の中学生を対象とした本調査を実施した。さら に、作成した尺度を用いて得られた知見から、環 境配慮行動を導く学習指導法に関して、どの程度 の提案が可能であるか考察した。その結果、以下 のことが明らかになった。

1）木材を用いたものづくり学習における中学 生の環境意識について把握するための調査 票を作成することができた。

2) 木材を用いたものづくり学習における中学 生の環境意識構造について検討した結果、 因子分析によって5因子を抽出することが 
できた。

3）学年における因子と因子得点の平均值によ る分析を行った結果、学年が上がることに より生じる「自然体験活動への意欲」と「木 材加工への興味・関心」の $2 つ の$ 環境意識 の低下を防ぐためには、木や森の多様な機 能に関する学習内容をカリキュラムに取り 入れることが有効であるという、学習指導 法を提案することができた。

4）性別における因子と因子得点の平均值によ る分析を行った結果、男子の「ものづくり を動因とした環境問題への興味・関心」と 「日常生活における環境保全意識」の $2 つ の$ 環境意識を向上させるための手立てとして、 製作品の設計に学習指導の重点を置くこと が重要であるという、指摘を行うことがで きた。

\section{引用文献}

広瀬幸雄, 1994, 「環境配慮行動の規定因につい て」, 『社会心理学研究』, $10: 44-45$.

鎌原雅彦 - 宮下一博 - 大野木裕明 - 中澤潤, 1998,「心理マニュアル 質問紙法」, 北大路書 店.

環境省, 2004,「環境保全の意欲の増進及び環境 教育の推進に関する基本的な方針」.

橘田紘洋, 1990, 「普通教育における木材加工教 育の役割と教育適時性について」,『愛知教育大 学研究報告』, $39: 85-96$.

木村彰孝 - 寺床勝也 - 吉見圭太郎 - 小林大介, 2009,「ものづくり学習における環境問題を扱 う方法の検討と授業実践しい-グループによる 材料取りを通して-」、『鹿児島大学教育学部教 育実践研究紀要』, $19: 89-91$.

黒澤春香・村松浩幸 ·島田英昭, 2012, 「環境お よび環境教育に対する意識尺度の開発」、『信州 大学教育学部研究論文集』, $5: 1-13$.

文部科学省 (a), 2008, 『中学校学習指導要領解説 技術・家庭科』，教育図書， 19 .

文部科学省 (b), 2008, 『中学校学習指導要領解説 技術・家庭科』, 教育図書, 18 .
中村洋介, 2009, 「中学校におけるダムの環境学 習」,『環境教育』, 18(3)：47-52.

中野正俊-千原考司, 2007, 「児童生徒の環境配 慮行動を規定する要因の検討」、『滋賀大学教育 学部紀要 教育学科』, $57:$ 153-160.

下山田隆, 2008,「中学校における環境教育に関 する体験プログラムの開発」、『環境教育』, 18(2) : 26-35.

杉村正敏・谷口敦哉・今井一馬, 1999,「ライフ サイクルアセスメントの概念を取り入れた廃棄 木材利用教材製造を通して考える環境調和型製 品に関する教育」，『環境教育』，9(2)：12-23. 諏訪博彦 · 山本仁志 · 岡田勇 · 太田敏澄, 2006,

「環境配慮行動を促す環境教育プログラム開発 のためのパスモデルの構築」、日本社会情報学 会誌』, 18(1) : 59-70.

岳野公人, 2013 ,「ものづくりによる環境教育教 材の開発」, 『愛知教育大学研究報告, 芸術 - 保 健体育·家政・技術科学・創作編』, 62 : 67-71.

岳野公人・笠木哲也， 2007 , 「里山におけるもの づくり教材開発と環境教育の実践」、環境教 育』, 16(2) : 59-65.

岳野公人 ·鬼藤明仁, 2008 , 「中学生におけるも のづくり学習の意義に関する一考察」、日本産 業教育学会』, 50(3) : 1-10.

田口浩継, 2010,「児童期の生活体験と木材利用 意識に関する一考察」, 『研究論文集 - 教育系 · 文系の九州地区国立大学間連携論文集 $-』, 4$ (2) : 1-10. 